\title{
TAX EVASION AND COMPETITION
}

\author{
LASZLO GOERKE \\ MARCO RUNKEL
}

\section{CESIFO WORKING PAPER NO. 2104 \\ CATEGORY 1: PUBliC FinANCE \\ SEPTEMBER 2007}

\footnotetext{
An electronic version of the paper may be downloaded

- from the SSRN website: Www.SSRN.com

- from the RePEc website: Www.RePEc.org

- from the CESifo website: www.CESifo-group.org/wp
} 


\title{
TAX EVASION AND COMPETITION
}

\begin{abstract}
Using a Cournot oligopoly model with an endogenous number of firms and evasion of indirect taxes, this paper shows that more intense competition may have the negative sideeffect of eroding tax revenues by increasing tax evasion. This will be the case if market entry costs decrease. A similar result will hold if marginal production costs fall and demand is either weakly concave or convex and inelastic. The desirable result of more competition, less evasion and higher tax revenues will be obtained if (a) marginal production costs fall and demand is convex and elastic or (b) the demand elasticity increases.
\end{abstract}

JEL Code: H25, H26, L13, L51.

Keywords: competition, firms, market power, tax evasion, tax revenues.

Laszlo Goerke

Eberhard Karls University Tübingen

Department of Economics

Melanchthonstr. 30

72074 Tübingen

Germany

Laszlo.Goerke@uni-tuebingen.de
Marco Runkel

University of Munich

Department of Economics

Ludwigstr. 28 / Vgb. / III

80539 Munich

Germany

Marco.Runkel@Irz.uni-muenchen.de

The first author would like to thank CESifo for its hospitality, as the initial version of the paper was written while visiting Munich. We also appreciate the helpful comments of the participants of a research seminar at the University of Munich, the CESifo Area Conference on Public Sector Economics, the Annual Meeting of the Verein für Socialpolitik (Bayreuth), and the 62nd Congress of the International Institute of Public Finance (Paphos). The usual disclaimer applies. 


\section{Introduction}

Competition policy is an important component of economic policy. The European Commission, for example, runs a branch concerned with antitrust and liberalisation, and also every member state of the European Union has its own national competition authority. Such institutions usually aim at reducing market power and intensifying the degree of competition among firms. For instance, the European Commission states that "[c]ompetition is a basic mechanism of the market economy and encourages companies to provide consumers products that consumers want. It encourages innovation, and pushes down prices. In order to be effective, competition needs suppliers who are independent of each other, each subject to the competitive pressure exerted by the others." "1 Opening markets and thereby intensifying competition was also one of the goals of introducing a common market in Europe. The central point of this paper is that competition policies may have negative side effects undermining the positive effects of increasing competition. In our paper, these side effects are triggered by tax evasion. We show that reducing market power may induce firms to intensify tax evasion activities and, as a consequence, tax revenues may fall.

These results are obtained using a Cournot oligopoly model with endogenous market entry. The number of firms is determined by a zero-profit condition, stating that expected profits equal market entry costs. Those firms entering the market produce a homogenous good at constant marginal costs. The good is sold to consumers whose demand is captured by a standard (inverse) demand function. Firms have to pay an ad valorem sales tax but may evade part of their tax duty. ${ }^{2}$ If a firm is detected evading taxes, it will be penalised. The degree of tax evasion is measured either by the absolute amount of taxes evaded successfully or the tax evasion ratio. This ratio is defined as the amount of taxes evaded, relative to hypothetical tax revenues, i.e. tax revenues in the absence of evasion. We follow the industrial organization literature and measure the degree of market power by the Lerner-index which reflects the price-cost mark up, i.e. the difference between a firm's (after-tax) output price and marginal production costs, expressed as a percentage of the (after-tax) output price (e.g. Martin, 2001).

Within this model we analyze the effects of reductions in market entry costs and marginal production costs, as well as a greater price elasticity of commodity demand. Following Bliss

\footnotetext{
${ }^{1}$ See http://ec.europa.eu/comm/competition/antitrust/overview_en.html.

${ }^{2}$ Our choice of a sales tax is motivated by two empirical observations. First, during the last decades revenues from indirect taxes have become increasingly important. For example, in OECD countries VAT revenues as percentage of total tax revenues increased from $11.9 \%$ in 1965 to $17.9 \%$ in 1998 (OECD, 2001). Second, it is by now well known that, despite the governments' increasing reliance on indirect taxes, a substantial part of potential VAT revenues is lost through tax evasion (Keen and Smith 2006). Nevertheless, our basic results intuitively apply to other kinds of corporate taxes as well.
} 
and Di Tella (1997, p. 1002), who analyze the relation between corruption and competition when coining this term, we refer to "... deep competition (parameters), to distinguish them from measures of competition, such as the number of firms, that are defined from the equilibrium outcome". Restricting government policies to activities easing market entry or reducing - but not eliminating - the scope for setting prices, represents a plausible description of the policy space. This is because a government can hardly force firms to enter a market or to behave in a distinct manner in a market economy. Instead, competition policy can alter incentives by affecting the constraints under which firms optimise. Hence, changes in deep competition parameters can be interpreted to broadly reflect the above mentioned deregulation policies. Furthermore, such changes are triggered by globalization and economic integration like the European unification. In previous decades, these developments have considerably reduced barriers to enter foreign markets (e.g. Djankov et al., 2002, Conway et al., 2005, Dreher, 2006). Marginal production costs have fallen due to improved outsourcing and offshoring opportunities as well as increased competition on input markets (e.g. Girma and Görg, 2004). In addition, the price elasticity of demand has increased because of more comprehensive cross-border shopping activities and greater market transparency, for example, due to the internet.

Our analysis shows that a reduction in market entry costs intensifies competition by reducing the Lerner-index. At the same time, however, absolute tax evasion and the tax evasion ratio increase so that tax revenues may decline. Intuitively, the reason for this is that lower barriers to entry increase the number of firms and thereby reduce turnover per firm, as output per firm and the market price decline. Firms therefore use tax evasion as a substitute for the loss in market power. With respect to reductions in marginal production costs, results are less clearcut, but we are still able to identify cases in which tax evasion rises and tax revenues decline. This will be the case if demand is linear or concave, since turnover per firm again drops (even though, in contrast to a fall in entry costs, lower marginal production costs ceteris paribus provide the firms with an incentive to raise output). Under (strictly) convex demand, the effects of decreasing marginal costs depend on the price elasticity of demand. For elastic demand, the decline in the equilibrium price is moderate and the incentives to raise output are sufficiently strong to increase turnover per firm. Hence, firms evade relatively less taxes and tax revenues rise. As this argument is reversed for an inelastic demand function, however, we have a further case with rising tax evasion and decreasing tax revenues. Interestingly, a reduction in marginal production costs can not only erode tax revenues, but may also fail to improve the degree of competition among firms. The Lerner-index may increase since there is 
now a direct positive effect of the lower marginal costs on the Lerner-index which may overcompensate the decline in the market price. We finally show that an increase in the demand elasticity seems to be the best way to intensify competition, as it not only makes the negative effects of a decline in marginal production costs less likely, but by itself reduces the Lernerindex and enhances tax revenues due to a decline in the tax evasion ratio.

While there is huge number of articles on tax evasion by individuals, less attention has been paid to the analysis of tax evasion by firms ${ }^{3}$ and only one study has looked at the relationship between tax evasion and competition. Previous authors have investigated the incentives of tax evading firms under different market structures. Virmani (1989), Cremer and Gahvari (1992, 1993, 1999), Yaniv (1995) and Panteghini (2000) consider perfectly competitive firms, while Marrelli (1984), Kreutzer and Lee (1986, 1988), Wang and Conant (1988), Wang (1990), Yaniv (1995, 1996) and Lee (1998) focus on a monopoly. Oligopoly settings are investigated in Bayer and Cowell (2006) and Goerke and Runkel (2006). The former article analyzes the role of the audit rule, while the latter shows that output and evasion decisions will not be independent if the number of firms is endogenous. To the best of our knowledge, the only article on the relation between competition and tax evasion is the one by Marelli and Martina (1988). They conclude that tax evasion is the smaller, the more competitive the market is, given a symmetric duopoly or a setting with asymmetric costs, provided the costs differential is not too large. Hence, the result of Marelli and Martina (1988) contrasts with our finding that a higher degree of competition may raise tax evasion. There are mainly two reasons for the difference: First, Marelli and Martina (1988) focus on a conjectural variation parameter to model a change in competition, while we look at the impact of deep competition parameters. Second, Marelli and Martina (1988) assume decreasing absolute risk aversion. The less collusive the market, the smaller the profits are and the higher the risk aversion is. This provides firms with the incentive to evade less when competition becomes more intensive. To rule out such risk driven tax evasion, we suppose risk neutral firms. ${ }^{4}$

The paper is organized as follows. Section 2 presents the model and characterizes the market equilibrium. In Section 3 we determine the impact of the deep competition parameters on the market equilibrium. Section 4 summarises.

\footnotetext{
${ }^{3}$ The surveys by Alm (1999), Andreoni et al. (1998), Franzoni (2000a) and Slemrod and Yitzhaki (2002), focus on tax evasion by individuals. Recently the attention has shifted somewhat, since the reviews by Cowell (2004), Sandmo (2005), and Slemrod (2007) contain separate, but often short sections on tax evasion by firms.

${ }^{4}$ It is straightforward to show that under constant absolute risk aversion the degree of competition does not have an effect on tax evasion in the Marelli and Martina (1988) framework.
} 


\section{Model}

We consider a two stage game. In the first stage, firms decide whether to enter the market, comparing expected net profits with constant market entry costs. In the second stage, given the entry decision and thereby the number of firms, competition in quantities takes place. In this stage, firms have to pay an ad valorem sales tax, but may evade a part of their tax obligations. To ensure a subgame perfect equilibrium, we solve the model recursively.

Suppose $n \geq 1$ firms have entered the market in the first stage. Firm $i=1, \ldots, n$ produces $x_{i}$ units of a homogenous consumption good at constant marginal costs $c>0$. The quantity supplied by firm i's rivals is denoted by $X^{i}=\sum_{j \neq i}^{n} x_{j}$, and $X=x_{i}+X^{i}$ represents aggregate output of all firms. The (inverse) demand function $P(X)$ satisfies $P^{\prime}(X)<0$ and $\mathrm{P}^{\prime}(\mathrm{X})+\mathrm{x}_{\mathrm{i}} \mathrm{P}^{\prime \prime}(\mathrm{X})<0$. The latter condition states that the firms' output levels are strategic substitutes as defined by Bulow et al. (1985). In the standard Cournot oligopoly model without tax evasion, the assumption of strategic substitutes ensures that the firms' reaction curves are downward sloping and that the necessary conditions for stability are satisfied (Dixit, 1986). The implications in our model with tax evasion are the same since we will show below that, for a given number of firms, output decisions are independent of tax evasion.

The tax rate of the sales tax is denoted by $\tau \in] 0,1\left[\right.$. The true tax base of firm i reads $\mathrm{x}_{\mathrm{i}} \mathrm{P}(\mathrm{X})$. Firms may understate their turnover in order to evade taxes. Thus, firm $\mathrm{i}$ declares $\alpha_{\mathrm{i}} \in\left[0, \mathrm{x}_{\mathrm{i}} \mathrm{P}(\mathrm{X})\right]$ as tax base to the tax authority. Accordingly, evaded revenues of firm $\mathrm{i}$ are given by $\mathrm{x}_{\mathrm{i}} \mathrm{P}(\mathrm{X})-\alpha_{\mathrm{i}}$. With probability $\left.\left.1-\mathrm{q} \in\right] 0,1\right]$ tax evasion remains undetected and firm i's tax bill amounts to $\tau \alpha_{\mathrm{i}}$. In case of detection, taking place with probability q, firm i has to pay taxes on full revenues, $\mathrm{x}_{\mathrm{i}} \mathrm{P}(\mathrm{X})$, and, in addition, a penalty $\mathrm{F}\left[\mathrm{x}_{\mathrm{i}} \mathrm{P}(\mathrm{X})-\alpha_{\mathrm{i}}\right]$, as we do not consider amnesties or settlements (see, for example, Franzoni 2000b and Macho-Stadler and Pérez-Castrillo 2004). The penalty is increasing and strictly convex in evaded revenues $\mathrm{x}_{\mathrm{i}} \mathrm{P}(\mathrm{X})-\alpha_{\mathrm{i}}$, i.e. $\mathrm{F}^{\prime}[\bullet], \mathrm{F}^{\prime \prime}[\bullet]>0 .^{5}$ Moreover, we assume $\mathrm{F}(0)=0$, so honest firms go unpunished. As firms are risk neutral, the expected penalty $q \mathrm{~F}\left[\mathrm{x}_{\mathrm{i}} \mathrm{P}(\mathrm{X})-\alpha_{\mathrm{i}}\right]$ can, alternatively, be interpreted as a cost of evasion function (see Virmani 1989 and Cremer and Gahvari 1992, 1993 for such an interpretation).

\footnotetext{
${ }^{5}$ Our subsequent results would qualitatively also hold, if the penalty is assumed to be a function of taxes evaded.
} 
Firm i's expected profits in the second stage read

$$
\begin{aligned}
\Pi_{i}=q\left\{(1-\tau) x_{i} P\left(x_{i}+X^{i}\right)-c x_{i}-\right. & \left.F\left[x_{i} P\left(x_{i}+X^{i}\right)-\alpha_{i}\right]\right\} \\
& +(1-q)\left\{x_{i} P\left(x_{i}+X^{i}\right)-c x_{i}-\tau \alpha_{i}\right\} .
\end{aligned}
$$

The first bracketed term in equation (1) equals firm i's profits in case tax evasion is detected, while the second term represents profits if such activities remain undetected. Firm i maximizes $\Pi_{\mathrm{i}}$, simultaneously choosing output $\mathrm{x}_{\mathrm{i}}$ and declared revenues $\alpha_{\mathrm{i}}$, taking as given the output of all other firms $\mathrm{j} \neq \mathrm{i}$. We focus on an interior solution for the tax evasion problem throughout. ${ }^{6}$ The first-order conditions can be written as

$$
\begin{gathered}
\frac{\partial \Pi_{i}}{\partial \alpha_{i}}=-(1-q) \tau+q F^{\prime}\left[x_{i} P\left(x_{i}+X^{i}\right)-\alpha_{i}\right]=0 \\
\frac{\partial \Pi_{i}}{\partial x_{i}}=\left\{1-\tau-q F^{\prime}\left[x_{i} P\left(x_{i}+X^{i}\right)-\alpha_{i}\right]+(1-q) \tau\right\}\left[P\left(x_{i}+X^{i}\right)+x_{i} P^{\prime}\left(x_{i}+X^{i}\right)\right]-c=0
\end{gathered}
$$

The second-order conditions are satisfied since $\mathrm{F}^{\prime \prime}>0$ and $\mathrm{P}^{\prime}+\mathrm{x}_{\mathrm{i}} \mathrm{P}^{\prime \prime}<0$ imply

$$
\frac{\partial^{2} \Pi_{i}}{\partial \alpha_{i}^{2}}=-q F^{\prime \prime}<0, \quad \frac{\partial^{2} \Pi_{i}}{\partial \alpha_{i}^{2}} \frac{\partial^{2} \Pi_{i}}{\partial x_{i}^{2}}-\left(\frac{\partial^{2} \Pi_{i}}{\partial x_{i} \partial \alpha_{i}}\right)^{2}=-q(1-\tau)\left(2 P^{\prime}+x_{i} P^{\prime \prime}\right) F^{\prime \prime}>0
$$

Therefore, the first-order conditions (2) and (3) determine firm i's profit-maximizing choices of declared revenue, $\alpha_{i}{ }^{*}$, and output, $\mathrm{x}_{\mathrm{i}}{ }^{*}$.

The solution to equations (2) and (3) for $\mathrm{i}=1, \ldots, \mathrm{n}$ represents the Nash equilibrium in the second stage of our oligopoly model. It is straightforward to show that the equilibrium is symmetric, i.e. $x_{i}^{*}=x^{*}, \alpha_{i}^{*}=\alpha^{*}$ and $X^{*}=x_{i}^{*}+X^{i *}=n x^{*}$ for all $i=1, \ldots, n{ }^{7}$ Using the symmetry property in equations (2) and (3) yields

$$
\begin{aligned}
& A:=-(1-q) \tau+q F^{\prime}\left[x^{*} P\left(n x^{*}\right)-\alpha^{*}\right]=0, \\
& B:=(1-\tau)\left[P\left(n x^{*}\right)+x^{*} P^{\prime}\left(n x^{*}\right)\right]-c=0 .
\end{aligned}
$$

\footnotetext{
${ }^{6}$ An interior solution $\left.\alpha_{\mathrm{i}} \in\right] 0, \mathrm{x}_{\mathrm{i}} \mathrm{P}(\mathrm{X})\left[\right.$ will be warranted, if $0<(1-\mathrm{q}) \tau<\mathrm{qF}^{\prime}\left[\mathrm{x}_{\mathrm{i}} \mathrm{P}(\mathrm{X})\right]$. Models of indirect tax evasion which investigate the determinants of complete evasion or honesty are looked at by Virmani (1989) or Cremer and Gahvari (1992), for example.

${ }^{7}$ Suppose the opposite is true, i.e. there are at least two firms $\mathrm{j}$ and $\mathrm{k}$ with $\mathrm{x}_{\mathrm{j}}{ }^{*} \neq \mathrm{x}_{\mathrm{k}}{ }^{*}$. From (2) and (3) we can then derive $(1-\tau)\left(x_{j}{ }^{*}-x_{k}{ }^{*}\right) P^{\prime}=0$ which contradicts $x_{j}^{*} \neq x_{k}{ }^{*}$. Thus, $x_{i}{ }^{*}=x^{*}$ for all $i=1, \ldots, n$. Equation (2) then implies $\alpha_{i}^{*}=\alpha^{*}$ for all $i=1, \ldots, n$.
} 
These equations have the usual interpretation. According to (5), each firm declares an amount of revenues in equilibrium so that the expected marginal tax savings from evasion equal the expected marginal penalty, while (6) states that the equilibrium output of each firm equates after-tax marginal revenues and marginal costs. Equation (6) also shows that for a given number of firms the standard independence result holds, according to which a firm's output choice is unaffected by its evasion activities (e.g. Yaniv, 1995). As we will see below, however, evasion alters the incentives to enter the market. Accordingly, the output decision is no longer independent from tax evasion activities. This result, established by Goerke and Runkel (2006), also holds in the present setting. Moreover, equation (5) indicates that the absolute amount of revenues evaded per firm, $\mathrm{x} * \mathrm{P}\left(\mathrm{n}^{*} \mathrm{x}^{*}\right)-\alpha^{*}$, is affected neither by marginal production costs, nor by market entry costs or the price elasticity of demand, which we will formally introduce below. This is plausible as marginal tax savings from evasion activities are solely determined by the tax rate and the detection probability. Hence, we can treat taxes evaded per firm as a constant. It has to be emphasised, though, that this property does not prevent a relation between evasion and competition. Changes in the degree of competition are usually accompanied by variations in the number of firms and, thus, aggregate tax evasion. Moreover, the importance of tax evasion may better be measured in relation to the size of the market which, of course, is also related to the degree of competition.

Equations (5) and (6) jointly determine $x^{*}$ and $\alpha^{*}$ as functions of the model parameters and the number of firms $n$. Inserting these functions into equation (1) defines the equilibrium level of expected profits $\Pi^{*}$ of a single firm in stage 2 . If we differentiate $\Pi^{*}$ with respect to $\mathrm{n}$ and take into account (5), (6), and $\mathrm{dx} * / \mathrm{dn}$ determined by (6), we will obtain

$$
\frac{\mathrm{d} \Pi^{*}}{\mathrm{dn}}=(1-\tau) \mathrm{x}^{* 2} \mathrm{P}^{\prime} \frac{2 \mathrm{P}^{\prime}+\mathrm{x}^{*} \mathrm{P}^{\prime \prime}}{(\mathrm{n}+1) \mathrm{P}^{\prime}+\mathrm{nx} \mathrm{x}^{*} \mathrm{P}^{\prime \prime}}<0
$$

where the sign follows from $\mathrm{P}^{\prime}<0$ and $\mathrm{P}^{\prime}+\mathrm{x}^{*} \mathrm{P}^{\prime \prime}<0$. Equation (7) implies that equilibrium expected profits $\Pi^{*}$ in stage 2 decline with the number of firms entering the market in stage 1 . Having characterized the equilibrium in the second stage, we now turn to the first stage in which firms decide whether to enter the market. In doing so, they take into account the properties of the equilibrium in the second stage. If a firm enters, it will incur market entry costs $\Gamma \geq 0$. These costs are the same for all potential entrants. Since $\Pi^{*}$ declines in the number of firms, entry continues until equilibrium expected second stage profits $\Pi^{*}$ equal market entry costs $\Gamma$ or, equivalently, until 


$$
\mathrm{Z}:=(1-\tau) \mathrm{x}^{*} \mathrm{P}\left(\mathrm{n}^{*} \mathrm{x}^{*}\right)-\mathrm{cx} \mathrm{x}^{*}-\mathrm{qF}\left[\mathrm{x}^{*} \mathrm{P}\left(\mathrm{n}^{*} \mathrm{x}^{*}\right)-\alpha^{*}\right]+(1-\mathrm{q}) \tau\left[\mathrm{x}^{*} \mathrm{P}\left(\mathrm{n}^{*} \mathrm{x}^{*}\right)-\alpha^{*}\right]-\Gamma=0,
$$

where $n^{*}$ denotes the equilibrium number of firms entering the market in the first stage. Strictly speaking, $\mathrm{n}^{*}$ is an integer variable. For the sake of tractability, and as usual in oligopoly models with an endogenous number of firms (Katsoulacos and Xepapadeas 1995), we treat $n^{*}$ as a continuous variable that approximates the true integer value.

The overall equilibrium of our two stage model is characterized by equations (5), (6) and (8), which determine the equilibrium number of firms, $\mathrm{n}^{*}$, equilibrium output, $\mathrm{x}^{*}$, and equilibrium declared revenues, $\alpha^{*}$, as functions of the model parameters. Of special interest in the subsequent analysis are the parameters which, in the introduction, we referred to as deep competition parameters, i.e. market entry costs, $\Gamma$, marginal production costs, $\mathrm{c}$, and the price elasticity of demand (which we shall introduce formally below). The focus of our analysis in the next section will be on the question of how these parameters influence the degree of competition, tax evasion and tax revenues in the market equilibrium of the industry.

The degree of competition is inversely related to the firms' market power which, in turn, can be measured by the Lerner-index, i.e. the difference between the (after-tax) output price and marginal production costs, relative to the (after-tax) output price. The Lerner-index reads

$$
\mathrm{L}:=\frac{(1-\tau) \mathrm{P}\left(\mathrm{n}^{*} \mathrm{x}^{*}\right)-\mathrm{c}}{(1-\tau) \mathrm{P}\left(\mathrm{n}^{*} \mathrm{x}\right)}
$$

Note that in computing the Lerner-index we ignore tax evasion activities. The reason is that the equilibrium second stage profits of a single firm can be written as $\Pi^{*}=(1-\tau) \mathrm{X}^{*} \mathrm{P}-$ $\mathrm{cx}^{*}+\mathrm{k}$ where $\mathrm{k}:=\mathrm{qF}\left(\mathrm{x} * \mathrm{P}-\alpha^{*}\right)-(1-\mathrm{q}) \tau\left[\mathrm{x} * \mathrm{P}-\alpha^{*}\right]$ is independent of the deep competition parameters (remember that $\mathrm{x} * \mathrm{P}-\alpha^{*}$ does not depend on the deep competition parameters according to equation (5)). Hence, a firm's equilibrium profits in the presence of tax evasion equal the firm's equilibrium profits without tax evasion plus a constant term. It is therefore suitable to use the same indicator of market power as in a case where no tax evasion occurs.

We finally need to specify tax revenues and the measures of tax evasion. Dividing absolute revenues evaded per firm, $x^{*} \mathrm{P}\left(\mathrm{x}^{*} \mathrm{n}^{*}\right)-\alpha^{*}$, by the actual turnover, $\mathrm{x}^{*} \mathrm{P}\left(\mathrm{x}^{*} \mathrm{n}^{*}\right)$, we obtain relative revenues evaded per firm. Absolute and relative tax evasion per firm is used as indicator of tax evasion by Marelli and Martina (1988), Virmani (1989) and Cremer and Gahvari (1992, 1993, 1999), for example. Marelli (1984) points out that in a setting with several firms, total evasion in the entire market may be of interest. We therefore introduce the absolute amount of taxes evaded successfully as 


$$
H:=(1-q) \tau n *\left[x^{*} P\left(n^{*} x^{*}\right)-\alpha^{*}\right]
$$

As an alternative measure we will investigate relative aggregate tax evasion. Let hypothetical tax revenues, i.e. the amount of tax revenues which would arise without evasion, be given by $\Phi:=\tau \mathrm{n}^{*} \mathrm{x} * \mathrm{P}(\mathrm{x} * \mathrm{n} *)$. Dividing $\mathrm{H}$ by $\Phi$ gives the tax evasion ratio

$$
\mathrm{T}:=\frac{\mathrm{H}}{\Phi}=\frac{(1-\mathrm{q})\left[\mathrm{x}^{*} \mathrm{P}\left(\mathrm{n}^{*} \mathrm{x}^{*}\right)-\alpha^{*}\right]}{\mathrm{x}^{*} \mathrm{P}\left(\mathrm{x}^{*} \mathrm{n}^{*}\right)}=(1-\mathrm{q})\left(1-\frac{\alpha^{*}}{\mathrm{x}^{*} \mathrm{P}\left(\mathrm{n}^{*} \mathrm{x}^{*}\right)}\right),
$$

which represents the fraction of aggregate tax revenues evaded successfully. The advantage of the tax evasion ratio $\mathrm{T}$ as an indicator of evasion behaviour is that it describes tax evasion relative to the size of the market. It therefore also captures changes in the firms' activities due to competition policy. Finally, tax revenues of the government are given by

$$
\mathrm{R}:=\Phi-\mathrm{H}=\mathrm{H}\left(\frac{1}{\mathrm{~T}}-1\right)
$$

Tax revenues $\mathrm{R}$ equal the difference between hypothetical (or maximal) tax revenues and the absolute amount of taxes evaded successfully by the firms.

\section{Variations in Deep Competition Parameters}

The effects of a change in a parameter $\theta$ on the endogenous variables can be obtained by totally differentiating the equilibrium conditions (5), (6), and (8). This gives:

$$
\left[\begin{array}{ccc}
\mathrm{Z}_{\mathrm{n}} & \mathrm{Z}_{\alpha} & \mathrm{Z}_{\mathrm{x}} \\
\mathrm{A}_{\mathrm{n}} & \mathrm{A}_{\alpha} & \mathrm{A}_{\mathrm{x}} \\
\mathrm{B}_{\mathrm{n}} & \mathrm{B}_{\alpha} & \mathrm{B}_{\mathrm{x}}
\end{array}\right]\left[\begin{array}{c}
\mathrm{dn}^{*} \\
\mathrm{~d} \alpha^{*} \\
\mathrm{dx}^{*}
\end{array}\right]=\left[\begin{array}{l}
-\mathrm{Z}_{\theta} \\
-\mathrm{A}_{\theta} \\
-\mathrm{B}_{\theta}
\end{array}\right] \mathrm{d} \theta .
$$

From (8) we obtain $\mathrm{Z}_{\mathrm{n}}=(1-\tau) \mathrm{X}^{* 2} \mathrm{P}^{\prime}<0, \mathrm{Z}_{\alpha}=0, \mathrm{Z}_{\mathrm{X}}=\left(\mathrm{n}^{*}-1\right)(1-\tau) \mathrm{X}^{*} \mathrm{P}^{\prime} \leq 0$, where use has been made of equations (5) and (6). Equation (5) yields $A_{n}=q x^{* 2} F^{\prime \prime} P^{\prime}<0, A_{\alpha}=-q F^{\prime \prime}<0$ and $A_{x}=q\left(P+n^{*} x^{*} P^{\prime}\right) F^{\prime \prime}$. Finally, $B_{n}=(1-\tau) x^{*}\left(P^{\prime}+x^{*} P^{\prime \prime}\right), B_{\alpha}=0, B_{x}=(1-\tau)\left[\left(n^{*}+1\right) P^{\prime}+\right.$ $\left.\mathrm{n}^{*} \mathrm{x}^{*} \mathrm{P}^{\prime \prime}\right]<0$ is obtained by differentiating (6). The determinant of the matrix on the LHS of (13) is $\tilde{\Delta}:=-\mathrm{qx}^{* 2}(1-\tau)^{2}\left(2 \mathrm{P}^{\prime}+\mathrm{x}^{*} \mathrm{P}^{\prime \prime}\right) \mathrm{P}^{\prime} \mathrm{F}^{\prime \prime}<0$. For notational convenience, we define $\Delta:=-\tilde{\Delta} / \mathrm{q}(1-\tau) \mathrm{F}^{\prime \prime}>0$.

Let us first investigate the impact of a fall in market entry costs, $\Gamma$. These costs comprise, for example, initial investment costs, licence fees, or the monetary and time costs of fulfilling government regulations (Djankov et al. 2002, Conway et al. 2005). A decline in $\Gamma$ may be due 
to deregulation policies, for example. In many countries, competition authorities have opened markets of key industries like the transport or telecommunication sector by lowering the legal and economic requirements potential producers have to fulfil when entering the market. Other reasons for declining entry costs are globalization and economic integration which reduce trade and entry barriers or grant access to new information technologies like the internet making it easier for firms to enter markets. ${ }^{8}$ Formally, from equations (5), (6) and (8) we have $\mathrm{A}_{\Gamma}=\mathrm{B}_{\Gamma}=0$ and $\mathrm{Z}_{\Gamma}=-1$. Setting $\theta=\Gamma$ in equation (13) then implies

$$
\begin{aligned}
\frac{\mathrm{dn} n^{*}}{\mathrm{~d} \Gamma} & =\frac{\left(\mathrm{n}^{*}+1\right) \mathrm{P}^{\prime}+\mathrm{n}^{*} \mathrm{x}^{*} \mathrm{P}^{\prime \prime}}{\Delta}<0, \\
\frac{\mathrm{d}\left[\mathrm{x}^{*} \mathrm{P}\left(\mathrm{n}^{*} \mathrm{x}^{*}\right)\right]}{\mathrm{d} \Gamma}=\frac{\mathrm{d} \alpha^{*}}{\mathrm{~d} \Gamma} & =-\frac{\mathrm{x}^{*}\left\{\mathrm{P}^{\left.\left(\mathrm{P}^{\prime}+\mathrm{x}^{*} \mathrm{P}^{\prime \prime}\right)-\mathrm{x}^{*} \mathrm{P}^{\prime 2}\right\}}\right.}{\Delta}>0, \\
\frac{\mathrm{dx}}{\mathrm{d} \Gamma} & =-\frac{\mathrm{x}^{*}\left(\mathrm{P}^{\prime}+\mathrm{x}^{*} \mathrm{P}^{\prime \prime}\right)}{\Delta}>0 .
\end{aligned}
$$

where we used the fact that $x^{*} \mathrm{P}\left(\mathrm{n}^{*} \mathrm{x}^{*}\right)-\alpha^{*}$ is constant in (15). From (14) and (16) follows

$$
\frac{\mathrm{d}\left(\mathrm{n}^{*} \mathrm{x}^{*}\right)}{\mathrm{d} \Gamma}=\frac{\mathrm{x}^{*} \mathrm{P}^{\prime}}{\Delta}<0
$$

Equation (14) shows that lower entry costs raise the equilibrium number of firms, $\mathrm{n}^{*}$, since more firms find it profitable to enter the market. According to (16), the increase in the number of firms reduces output per firm, $\mathrm{x}^{*}$. The reason is that output levels of the firms are strategic substitutes. Nevertheless, the additional output of the new firms entering the market more than outweighs the decline in the incumbents' production. Aggregate output, $\mathrm{n}^{*} \mathrm{x}^{*}$, grows as shown by equation (17). As consequence, the market price, $\mathrm{P}$, and turnover per firm, $\mathrm{x} * \mathrm{P}$, as well as declared revenues, $\alpha^{*}$, shrink according to equation (15).

Having determined the effects of entry costs on market outcomes, it is straightforward to specify the impact of a decline in $\Gamma$ on competition and tax evasion. The fall in the output price, $\mathrm{P}$, is equivalent to a drop in the Lerner-index, $\mathrm{L}$, as marginal production costs, $\mathrm{c}$, are unaffected. From equation (5) we know that absolute evasion per firm, $x^{*} P\left(n^{*} x^{*}\right)-\alpha^{*}$, is constant. Since the number of firms, $\mathrm{n}^{*}$, increases as $\Gamma$ declines, absolute tax evasion, $\mathrm{H}$, has to rise. Moreover, (15) indicates that turnover per firm, $\mathrm{x}^{*} \mathrm{P}\left(\mathrm{n}^{*} \mathrm{x}^{*}\right)$, falls. This implies an increase in the tax evasion ratio, T. Finally, since $\mathrm{H}$ and $\mathrm{T}$ move into the same direction, the

\footnotetext{
${ }^{8}$ While governments or competition agencies can alter market entry costs, they will never be able to abolish them completely as such costs also include components arising in the absence of government intervention.
} 
effect of a change in market entry costs, $\Gamma$, on tax revenues, $R$, is uncertain. These findings are summarized in

Proposition 1: A reduction in market entry costs, $\Gamma$, reduces the Lerner-index, $L$, but raises absolute tax evasion, $H$, and the tax evasion ratio, T. The effect on tax revenues, $R$, is ambiguous.

Proposition 1 reveals a basic trade-off between competition and tax evasion: If firms are more constrained in their pricing behaviour because their number has risen and the price-cost markup has fallen, owing to a reduction in market entry costs, they will select an alternative means of raising profits. In our model, this alternative avenue is constituted by tax evasion. Hence, there is an inverse relation between the intensity of competition and the degree of tax evasion. The model therefore provides a formalisation of Shleifer's (2004) claim that competition may decrease ethical (i. e. legal) behaviour. Intuitively, the decline in market entry costs increases the number of firms and so reduces the market power of each firm. Both output per firm and the market price fall. The consequence is that turnover per firm goes down. Each firm evades a larger share of its turnover. Firms therefore use tax evasion as a substitute for the loss in market power. Proposition 1 also shows that the reduction in market entry costs may decrease tax revenues. This will unambiguously be the case if $\mathrm{P}(\mathrm{X})+\mathrm{X}^{*} \mathrm{n}^{*} \mathrm{P}^{\prime}(\mathrm{X})<0$ holds. ${ }^{9}$ In such a situation, the positive effect of increasing the degree of competition is not only accompanied by the negative effect of increasing tax evasion, but also by a decline in public funds.

While the relationship between tax evasion and competition caused by a variation in market entry costs is unambiguous, the effects of a change in marginal production costs, c, are more uncertain. Governments can affect this deep competition parameter by liberalising input markets, slashing the bureaucratic burden imposed on firms or simplifying international trade in inputs. The derivatives of (5), (6), and (8) with respect to the deep competition parameter c yields $A_{c}=0, B_{c}=-1$ and $Z_{c}=-x^{*}$. By setting $\theta=c$ in (13), we then obtain

$$
\begin{aligned}
& \frac{\mathrm{dn}^{*}}{\mathrm{dc}}=\frac{\mathrm{x}^{*}\left(2 \mathrm{P}^{\prime}+\mathrm{n}^{*} \mathrm{x}^{*} \mathrm{P}^{\prime \prime}\right)}{\Delta}, \\
& \frac{\mathrm{dx} \mathrm{x}^{*}}{\mathrm{dc}}=-\frac{\mathrm{x}^{*} \mathrm{P}^{\prime \prime}}{\Delta},
\end{aligned}
$$

\footnotetext{
${ }^{9}$ An example is the case of an isoelastic demand function $\mathrm{P}(\mathrm{X})=\mathrm{X}^{-1 / \eta}$ which we will use frequently in the subsequent analysis. For this demand function it straightforward to show that a decline in $\Gamma$ will exert a negative effect on $\mathrm{R}$ if $\eta \leq 1$. In case of $\eta>1$, the effect of $\Gamma$ on $\mathrm{R}$ is ambiguous.
} 


$$
\frac{\mathrm{d}\left[\mathrm{x}^{*} \mathrm{P}\left(\mathrm{n}^{*} \mathrm{x}^{*}\right)\right]}{\mathrm{dc}}=\frac{\mathrm{d} \alpha^{*}}{\mathrm{dc}}=-\frac{\mathrm{x}^{*}}{\Delta}\left(\mathrm{PP}^{\prime \prime}-2 \mathrm{P}^{\prime 2}\right) .
$$

Equations (18) and (20) yield

$$
\frac{\mathrm{d}\left(\mathrm{n}^{*} \mathrm{x}^{*}\right)}{\mathrm{dc}}=\frac{2 \mathrm{x}^{*} \mathrm{P}^{\prime}}{\Delta}<0
$$

Equation (21) shows that a decline in marginal costs, c, increases aggregate output and, thus, lowers the equilibrium price P. In contrast to variations in market entry costs, however, the signs of all other effects are ambiguous. The reason is that a change in marginal production costs does not only have a first-order effect on the number of firms via equation (8), but by equation (6) also on the output per firm: Reducing c relaxes the zero profit condition (8), so the number of firms increases ceteris paribus and output per firm declines according to the assumption of strategic substitutes. But by the marginal condition (6) lower marginal production costs ceteris paribus induce each firm to raise output. As a consequence there is a negative impact on the number of firms. Overall, we obtain two countervailing effects on the number of firms, the output per firm and, thus, turnover per firm. As shown by (18) - (20) the sign of the sum of both effects depends on the curvature of the demand function.

To reduce the ambiguity captured by equations (18) - (20), let us first take a closer look at the case of a concave or linear demand function. Taking into account $\mathrm{P} "<0$ in (18) - (20) implies that the decline in marginal production costs increases the number of firms and reduces output and turnover per firm. Intuitively, for $\mathrm{P}^{\prime \prime}<0$ marginal revenues $\mathrm{P}\left(\mathrm{n}^{*} \mathrm{x}^{*}\right)+\mathrm{x}^{*} \mathrm{P}^{\prime}\left(\mathrm{n}^{*} \mathrm{x}^{*}\right)$ react quite sensitively to variations in output per firm (keeping constant the number of firms). As a consequence, the positive effect of a reduction in marginal costs, c, on output via the marginal condition (6) is small and the already known negative impact of a fall in $\mathrm{c}$ on output per firm via the zero profit condition (8) dominates. Output and turnover per firm therefore fall while the number of firms increases. Almost the same is true for $\mathrm{P}^{\prime \prime}=0$ except for the fact that under a linear demand function output per firm is constant. This is the case because the new positive effect via equation (6) exactly compensates the negative effect via equation (8).

With the help of this information we can now turn to the effects of a reduction in $\mathrm{c}$ on tax evasion and competition under a weakly concave demand function $\left(\mathrm{P}^{\prime \prime} \leq 0\right)$. Since a decline in marginal costs, c, raises the number of firms, $n^{*}$, and leaves unaltered revenues evaded per firm, $x^{*} \mathrm{P}\left(\mathrm{n}^{*} \mathrm{x}^{*}\right)-\alpha^{*}$, absolute tax evasion, $\mathrm{H}$, rises. The same is true for the tax evasion ratio, $\mathrm{T}$, as the turnover per firm, $\mathrm{x}^{*} \mathrm{P}\left(\mathrm{n}^{*} \mathrm{x}^{*}\right)$, declines. Because $\mathrm{H}$ and $\mathrm{T}$ move into the same 
direction, the effect on tax revenues, $\mathrm{R}$, is ambiguous. The impact on the Lerner index, $\mathrm{L}$, can be written as

$$
\frac{\mathrm{dL}}{\mathrm{dc}}=-\frac{\mathrm{P}^{\prime} \mathrm{x}^{*}}{(1-\tau) \mathrm{P}^{2} \Delta}\left[2 \mathrm{P}^{\prime}[(1-\tau) \mathrm{P}-\mathrm{c}]+(1-\tau) \mathrm{x}^{*} \mathrm{PP}^{\prime \prime}\right]
$$

For $\mathrm{P} " \leq 0$ this expression is unambiguously negative, implying that a decline in marginal production costs, c, raises the Lerner-index, L. These insights are summarized in

Proposition 2: Suppose the inverse demand function is weakly concave, i.e. $P^{\prime \prime} \leq 0$. Then, a reduction in marginal production costs, c, raises the Lerner-index, L, as well as absolute tax evasion, $H$, and the tax evasion ratio, $T$. The impact on tax revenues, $R$, is ambiguous.

Under a weakly concave demand function, a decline in marginal production costs increases tax evasion. Intuitively, lower marginal production costs imply a fall in the market price and output per firm (for $\mathrm{P}^{\prime \prime}<0$ ). Turnover per firm therefore shrinks and each firm increases the share of revenues evaded. Despite the fact that absolute tax evasion per firm remains constant, total absolute tax evasion goes up since more firms enter the market. As a consequence, tax revenues may be lowered. This is the same line of reasoning as for variations in market entry costs, characterized by Proposition 1. However, Proposition 2 reveals an important difference between the two deep competition parameters. While a reduction in entry costs decreases market power of firms, a decline in marginal production costs exerts exactly the opposite effects on the degree of competition. The reason is that, in contrast to variations in $\Gamma$, a decline in c has a direct positive effect on the Lerner-index, L. For a weakly concave demand function this effect is stronger than the fall in the market price $\mathrm{P}$ so that the decline in $\mathrm{c}$ unambiguously increases L. Lower marginal production costs may therefore not only worsen the situation of public budgets but may even fail to ensure more intensive competition.

How will the insights of Proposition 2 be changed if we consider a strictly convex demand function? From equation (19) we see for $\mathrm{P}^{\prime \prime}>0$ that a decline in marginal costs, c, increases output per firm (because the positive effect via condition (6) is strong enough to outweigh the negative impact caused via the profit constraint (8)). But all other effects are indeterminate. In particular, due to the increase in output per firm and the decrease in the output price, $\mathrm{P}$, it is no longer clear how a fall in marginal costs will affect turnover per firm and, thus, tax evasion. It may well be that turnover goes up so that tax evasion is reduced. In addition, equation (22) shows that the effect of a variation in $\mathrm{c}$ on market power, as measured by the Lerner-index, L, is ambiguous for a strictly convex demand function. 
Nevertheless, we can obtain clear-cut results if we focus on the isoelastic demand function $\mathrm{P}(\mathrm{X})=\mathrm{X}^{-1 / \eta}$, where $\eta:=-\mathrm{P}(\mathrm{X}) /\left[\mathrm{XP}^{\prime}(\mathrm{X})\right]>0$ is the price elasticity of demand. This function is strictly convex as $\mathrm{P}^{\prime}(\mathrm{X})=-(1 / \eta) \mathrm{X}^{-(1+\eta) / \eta}<0$ and $\mathrm{P}^{\prime \prime}(\mathrm{X})=(1+\eta)\left(1 / \eta^{2}\right) \mathrm{X}^{-(1+2 \eta) / \eta}>0 .{ }^{10}$ The expressions in the numerator of (18) and (20) can then be calculated as $2 \mathrm{P}^{\prime}+\mathrm{n}^{*} \mathrm{x}^{*} \mathrm{P}^{\prime \prime}=(1-\eta)\left(1 / \eta^{2}\right) \mathrm{X}^{-(1+\eta) / \eta}$ and $\mathrm{PP}^{\prime \prime}-2 \mathrm{P}^{\prime 2}=-(1-\eta)\left(1 / \eta^{2}\right) \mathrm{X}^{-2(1+\eta) / \eta}$. Hence, the effects of a change in marginal productions costs, c, depend crucially on the demand elasticity. If demand is elastic $(\eta>1)$, we will obtain $\mathrm{dn} * / \mathrm{dc}<0$ and $\mathrm{d} \alpha^{*} / \mathrm{dc}=\mathrm{d}\left[\mathrm{x} * \mathrm{P}\left(\mathrm{n}^{*} \mathrm{x}^{*}\right)\right] / \mathrm{dc}<0$, i.e. a decline in marginal production costs raises the number of firms and turnover per firm. The reason is that, under an elastic demand, the increase in total output induces a moderate fall of the market price so that this effect is dominated by the growth in output per firm. If demand is inelastic $(\eta<1)$, we will obtain the opposite results, i.e. $\mathrm{dn} * / \mathrm{dc}>0$ and $\mathrm{d} \alpha * / \mathrm{dc}=\mathrm{d}\left[\mathrm{x} * \mathrm{P}\left(\mathrm{n}^{*} \mathrm{x} *\right)\right] / \mathrm{dc}>0$. The fall in the market price is now substantial and outweighs the increases in output so that turnover per firm declines. Marginal costs will not exert an effect on the number of firms and turnover per firm if $\eta=1$.

With this information we can again figure out the effects of $\mathrm{c}$ on tax evasion and competition. Since for $\eta>1(\eta<1)$ the number of firms, $\mathrm{n}^{*}$, rises (falls) in response to a decline in marginal costs, c, absolute tax evasion, $\mathrm{H}$, rises (falls) as well (remember that revenues evaded per firm, $\mathrm{x}^{*} \mathrm{P}\left(\mathrm{n}^{*} \mathrm{x}^{*}\right)-\alpha^{*}$, remain constant). In contrast, the tax evasion ratio, $\mathrm{T}$, will decrease (increase) if demand is elastic (inelastic) because the turnover per firm, $\mathrm{x}^{*} \mathrm{P}\left(\mathrm{n}^{*} \mathrm{x}^{*}\right)$, will be raised (lowered) if $\eta>1(\eta<1)$. As $\mathrm{H}$ and $\mathrm{T}$ move into opposite directions, the effect on tax revenues, $\mathrm{R}$, is now unambiguous, i.e. $\mathrm{R}$ increases (decreases) for $\eta>1(\eta<1)$. With respect to the Lerner-index, L (cf. equation (22)), we have to take into account that $2 \mathrm{P}^{\prime}[(1-$ $\tau) \mathrm{P}-\mathrm{c}]+\mathrm{x}^{*}(1-\tau) \mathrm{PP}^{\prime \prime}=-(1-\eta)\left(1 / \eta^{2}\right) \mathrm{X}^{*}(1-\tau) \mathrm{X}^{-2(1+\eta) / \eta}$ since $(1-\tau) \mathrm{P}-\mathrm{c}=-(1-\tau) \mathrm{X}^{*} \mathrm{P}^{\prime}$ according to equation (6). Inserting this into (22) proves $\mathrm{dL} / \mathrm{dc}>(<) 0$ if and only if $\eta>1$ $(\eta<1)$. Hence, a decline in marginal production costs, $\mathrm{c}$, will decrease (increase) the Lernerindex, $\mathrm{L}$, if demand is elastic (inelastic). These insights are summarized in

Proposition 3: Suppose $P(X)=X^{-1 / \eta}$ with $\eta>0$. If $\eta>1$, a reduction in marginal production costs, $c$, will decrease the Lerner-index, L, and the tax evasion ratio, $T$, but will increase absolute tax evasion, $H$, and tax revenues, $R$. Results are reversed for $\eta<1$, while a change in marginal production costs, $c$, will have no effect for $\eta=1$.

\footnotetext{
${ }^{10}$ It should be noted that under the isoelastic demand function, the existence of a market equilibrium requires that $n^{*}>1 / \eta$. Otherwise (6) is violated. We suppose this condition to be satisfied throughout.
} 
Proposition 3 shows that the results summarised in Proposition 1 on the relation between competition and tax evasion may be reversed if the focus shifts to another deep competition parameter. If the demand function is strictly convex and elastic, a decline in marginal production costs will reduce both market power, as measured by the Lerner index, L, and the tax evasion ratio, $\mathrm{T}$. Tax revenues, $\mathrm{R}$, will rise. A reduction in marginal production costs can then be evaluated positively since it not only intensifies competition, but also generates additional governmental revenues and mitigates the problem of tax evasion (at least evasion relative to non-evasion revenues). As these effects of a reduction in marginal costs will be reversed if demand is inelastic, however, we obtain a further case where a decline in marginal production costs not only fosters tax evasion, but also weakens competition. This insight even strengthens the result obtained in Proposition 2 as the impact of a fall in marginal production costs, c, on tax revenues is unambiguously negative when demand is convex and inelastic.

As argued in the introduction, the shape of the demand function itself may be a deep competition parameter. An increasing openness of economies will make it considerably easier for consumers to fall back on foreign products if domestic prices are increased. Consequently, the price elasticity of demand may have risen in the last decades due to the introduction of regional free trade areas. Furthermore, competition authorities can improve the consumers' knowledge concerning substitutes for the good under consideration, thus also raising the price elasticity of demand. To determine the impact of a higher elasticity on the market equilibrium we again focus on the isoelastic demand function $\mathrm{P}(\mathrm{X})=\mathrm{X}^{-1 / \eta}$ with $\eta>0$, but, for notational convenience, define $\beta:=-1 / \eta<0$ so that $\eta$ increases, if and only if $\beta$ goes up. To get clearcut results, we additionally suppose $n^{*} x^{*} \geq 1$, implying $\ln \left(n^{*} x^{*}\right) \geq 0$, i.e. a sufficiently large market. It then follows $\mathrm{P}(\mathrm{X})=\mathrm{X}^{\beta}, \quad \mathrm{P}^{\prime}(\mathrm{X})=\beta \mathrm{X}^{\beta-1}, \quad \mathrm{P}^{\prime \prime}(\mathrm{X})=\beta(\beta-1) \mathrm{X}^{\beta-2}, \quad \mathrm{~A}_{\beta}=-$ $\mathrm{qF}^{\prime \prime} \mathrm{x} * \beta+1 \mathrm{n}^{* \beta} \ln \left(\mathrm{n}^{*} \mathrm{x} *\right)<0, \quad \mathrm{~B}_{\beta}=(1-\tau) \mathrm{x}^{*} \beta_{\mathrm{n}} * \beta-1\left[1+(\mathrm{n} *+\beta) \ln \left(\mathrm{n}^{*} \mathrm{x} *\right)\right]>0 \quad$ and $\quad \mathrm{Z}_{\beta}=(1-$ $\tau) x^{* \beta+1} n * \beta \ln (n * x *)>0$ from equations (5), (6), and (8). Remember from footnote 10 that the existence of an equilibrium requires $n^{*}+\beta>0$. Setting $\theta=\beta$ and using $P$ and its derivatives in (13) yields ${ }^{11}$

$$
\frac{\mathrm{dn}^{*}}{\mathrm{~d} \beta}=\frac{(1-\tau) \beta \mathrm{x}^{* 2} \mathrm{n}^{* 2 \beta-2}}{\Delta}\left[\mathrm{n}^{*}-1-\left(\mathrm{n}^{*}+\beta\right) \ln \left(\mathrm{n}^{*} \mathrm{x}^{*}\right)\right]>0
$$

\footnotetext{
11 The sign of (23) can be proven as follows. Let $Q\left(n^{*}\right):=n^{*}-1-\left(n^{*}+\beta\right) \ln \left(n^{*} x^{*}\right)$. Differentiating $Q\left(n^{*}\right)$, taking into account that $d x^{*} / d n^{*}=-x^{*}\left(n^{*}+\beta-1\right) /\left[n^{*}\left(n^{*}+\beta\right)\right]$ according to (6), we obtain $Q^{\prime}\left(n^{*}\right)=\left(n^{*}-\right.$ $1) / n^{*}-\ln \left(n^{*} x^{*}\right)$ and $Q^{\prime \prime}\left(n^{*}\right)=\beta /\left[n^{*}\left(n^{*}+\beta\right)\right]<0$. This implies $Q^{\prime}(1)<0$. Since $Q^{\prime \prime}\left(n^{*}\right)<0$ for all $n^{*} \geq 1$, it follows that $\mathrm{Q}^{\prime}\left(\mathrm{n}^{*}\right)<0$ holds for all $\mathrm{n}^{*} \geq 1$. Similarly, we obtain $\mathrm{Q}(1)<0$. $\mathrm{Q}^{\prime}\left(\mathrm{n}^{*}\right)<0$ then yields $\mathrm{Q}\left(\mathrm{n}^{*}\right)<0$ for all $n^{*} \geq 1$. Using this insight in (23) implies $d n * / d \beta>0$.
} 


$$
\begin{aligned}
\frac{d\left[x^{*} P\left(n^{*} x^{*}\right)\right]}{d \beta}=\frac{d \alpha^{*}}{d \beta} & =-\frac{(1-\tau) \beta\left(n^{*}+\beta\right) x^{* 3 \beta+1} n^{* 3 \beta-3}}{\Delta}\left[1+\ln \left(n^{*} x^{*}\right)\right]>0 \\
\frac{d x^{*}}{d \beta} & =-\frac{\beta(1-\tau) x^{* 2 \beta+1} n^{* 2 \beta-2}}{\Delta}\left[1+\ln \left(n^{*} x^{*}\right)\right]>0,
\end{aligned}
$$

Further, using $\mathrm{Z}_{\beta}>0, \quad \mathrm{~B}_{\beta}>0$, as well as $\mathrm{n}^{*} \mathrm{~B}_{\mathrm{n}}-\mathrm{x}^{*} \mathrm{~B}_{\mathrm{x}}=-(1-\tau) \beta \mathrm{x}^{*} \mathrm{n}^{* \beta-1}>0$ and $\mathrm{x} * \mathrm{Z}_{\mathrm{x}}-\mathrm{n} * \mathrm{Z}_{\mathrm{n}}=-(1-\tau) \beta \mathrm{x}^{*}{ }^{\beta+1} \mathrm{n}^{*-1}>0$, the change in $\mathrm{n}^{*} \mathrm{x}^{*}$ can be written as

$$
\frac{d\left(n^{*} x^{*}\right)}{d \beta}=\frac{Z_{\beta}\left(n * B_{n}-x^{*} B_{x}\right)+B_{\beta}\left(x * Z_{x}-n * Z_{n}\right)}{(1-\tau) \Delta}>0 .
$$

The intuition underlying equations (23) to (26) is as follows: If demand becomes more elastic, producers will be more constrained in their pricing behaviour so that aggregate output increases, as indicated by (26). Though this implies that, ceteris paribus, the market price is reduced, turnover per firm rises for two reasons: First, taking total output as given, there is a (direct) positive effect of a higher price elasticity on the market price $\mathrm{P}\left(\mathrm{n}^{*} \mathrm{X}^{*}\right)=\mathrm{X}^{-1 / \eta}$. Second, the increase in the elasticity enhances marginal revenues $(1-\tau)\left[\mathrm{P}+\mathrm{x}^{*} \mathrm{P}^{\prime}\right]=(1-$ $\tau) \mathrm{X}^{*}\left(\mathrm{n}^{*}-1 / \eta\right)\left(\mathrm{n}^{*} \mathrm{x} *\right)-(1+\eta) / \eta$, ceteris paribus. As a consequence, output per firm $\mathrm{x}^{*}$ goes up according to (25). These two effects more than compensate the price decline due to higher aggregate output. Hence, if demand becomes more elastic, turnover per firm will rise as shown in (24).

The impact of a higher demand elasticity on the degree of competition and tax evasion is as follows: Since the number of firms, $\mathrm{n}^{*}$, goes up, absolute tax evasion, $\mathrm{H}$, will increase. In contrast, the tax evasion ratio, $T$, falls because turnover per firm, $x^{*} \mathrm{P}\left(\mathrm{n}^{*} \mathrm{x}^{*}\right)$, rises. The increase in $\mathrm{H}$ and the decrease in $\mathrm{T}$ imply that tax revenues, $\mathrm{R}$, rise. Since $(1-\tau) \mathrm{P}\left(\mathrm{n}^{*} \mathrm{x}^{*}\right)-\mathrm{c}>$ 0 from (6) and $x^{*} P\left(n^{*} x^{*}\right)-\alpha^{*}$ is constant, the rise in $x^{*}$ must induce a fall in $(1-\tau) P\left(x^{*} n^{*}\right)-$ c to ensure the zero-profit condition (8). This effect and the rise in turnover per firm, $\mathrm{x} * \mathrm{P}\left(\mathrm{n}^{*} \mathrm{x}^{*}\right)$, together imply a fall in the Lerner-index, L. In sum, we obtain

Proposition 4: Suppose $P(X)=X^{-1 / \eta}$ with $\eta>0$ and $n^{*} x^{*} \geq 1$. An increase in the price elasticity of demand, $\eta$, reduces the Lerner-index, $L$, and the tax evasion ratio, $T$, but increases absolute evasion, $H$, and tax revenues, $R$.

The rationale for Proposition 4 is the following. Since the number of firms rises, a higher price elasticity of demand reduces market power and thereby intensifies competition. At the same time, it raises turnover per firm implying that firms lower tax evasion relative to 
turnover. Even though absolute tax evasion increases, the reduction in the tax evasion ratio induces tax revenues to go up. In summary, the increase in the demand elasticity yields the same "double dividend" (more competition, more tax revenues) as the decline in marginal production costs when the demand is elastic (see Proposition 3). Put differently, an increase in the demand elasticity seems to be the best way to intensify competition as such a policy directly reduces tax evasion and, in addition, makes a case less likely in which a decline in marginal production costs exerts detrimental effects on competition and tax evasion.

\section{Summary and Policy Implications}

In this paper, we developed a Cournot oligopoly model with an endogenous number of firms and evasion of indirect taxes. The main question to be investigated was how changes in socalled deep competition parameters - such as market entry costs, marginal production costs and the price elasticity of demand- affect the degree of competition, tax evasion and tax revenues. It turned out that market power and tax evasion may be substitutes from the firms' point of view. For example, a decline in entry costs intensifies competition, but at the same time raises tax evasion and may even reduce tax revenues. A similar result will be realised if marginal production costs decline and demand is inelastic. In contrast, the desired effects more competition, less tax evasion and more tax revenues - will be obtained by a decline in marginal production costs if demand is elastic and by an increase in the demand elasticity.

To the extent that the deep competition parameters can actually be influenced by public policy - which we assumed throughout the analysis - our results have mainly two policy implications. First, opening markets by reducing entry barriers is not always a good choice. Many national competition authorities choose this option and try to the intensify competition by allowing more firms to enter the market. However, our analysis shows that such a policy may have to balance the positive effect on the degree of competition with the potentially negative consequences for public funds. It may even be the case that the competition authority has to restrict entry to avoid the loss in tax revenues. Second, our analysis suggests that the best way to lower the market power of firms is to make demand (more) elastic, for example by reducing trade barriers and thereby improving the consumers' opportunities for crossborder shopping. Such a policy not only leads to more competition among firms, but also raises tax receipts. Moreover, it makes less likely cases in which tax revenues (and the degree of competition) are lowered by a decline in marginal production costs. 


\section{References}

Alm, J. (1999), Tax Compliance and Tax Administration, in: Hildreth, W.B. and J.A. Richardson (eds), Handbook on Taxation, New York, NY: Marcel Dekker, Inc., 741768.

Andreoni, J., Erard, B. and J. Feinstein (1998), Tax Compliance, Journal of Economic Literature 36, 818-860.

Bayer, R. and F.A. Cowell (2006), Tax Compliance and Firms' Strategic Interdependence, University of Adelaide, Working Paper 2006-09.

Bliss, C. and R. Di Tella (1997), Does Competition Kill Corruption?, Journal of Political Economy 105, 1001-1023.

Bulow, J.I., Geanakoplos, J.D. and P.D. Klemperer (1985), Multimarket Oligopoly: Strategic Substitutes and Complements, Journal of Political Economy 93, 488-511.

Conway, P., Janod, V. and G. Nicoletti (2005), Product Market Regulation in OECD Countries, 1998 to 2003, OECD Economics Department Working Paper, No 419.

Cowell, F.A. (2004), Carrots and Sticks in Enforcement, in: Aaron, H. and J. Slemrod (eds), The Crisis in Tax Administration, Washington DC: Brookings Institution Press, 230275.

Cremer, H. and F. Gahvari (1992), Tax Evasion and the Structure of Indirect Taxes and Audit Probabilities, Public Finance/Finance Publiques 47, 351-65.

Cremer, H. and F. Gahvari (1993), Tax Evasion and Optimal Commodity Taxation, Journal of Public Economics 50, 261-75.

Cremer, H. and F. Gahvari (1999), Excise Tax Evasion, Tax Revenue, and Welfare, Public Finance Review 27, 77-95.

Dixit, A. (1986), Comparative Statics for Oligopoly, International Economic Review 27, 107122.

Djankov, S., La Porta, R., Lopez-de-Silanes, F. and A. Shleifer (2002), The Regulation of Entry, Quarterly Journal of Economics 117, 1-37.

Dreher, A. (2006), Does Globalization Affect Growth? Evidence from a New Index of Globalization, Applied Economics 38, 1091-1110.

Franzoni, L.A. (2000a), Tax Evasion and Tax Compliance, in: Bouckaert, B. and G. van de Geest (eds), Encyclopedia of Law and Economics, Vol. 4, Cheltenham: Edward Elgar, 52-94.

Franzoni, L.A. (2000b), Amnesties, Settlements and Optimal tax Enforcement, Economica 67 (266), 153-176.

Girma, S. and H. Görg (2004), Outsourcing, Foreign Ownership, and Productivity: Evidence from UK Establishment-level Data, Review of International Economics 12, 817-832.

Goerke, L. and M. Runkel (2006), Profit Tax Evasion under Oligopoly with Endogenous Market Structure, National Tax Journal 59, 851-857.

Katsoulacos, Y.S. and A.P. Xepapadeas (1995), Environmental Policy under Oligopoly with Endogenous Market Structure, Scandinavian Journal of Economics 97, 411-420.

Keen, M. and S. Smith (2006), VAT Fraud and Evasion: What Do We Know and What Can Be Done?, National Tax Journal 59, 861-887.

Kreutzer, D. and D.R. Lee (1986), On Taxation and Understated Monopoly Profits, National Tax Journal 39, 241-43.

Kreutzer, D. and D.R. Lee (1988), Tax Evasion and Monopoly Output Decisions: A Reply, National Tax Journal 41, 583-84.

Lee, K. (1998), Tax Evasion, Monopoly, and Nonneutral Profit Taxes, National Tax Journal 51, 333-38.

Macho-Stadler, I. and D. Pérez-Castrillo (2004), Settlement in Tax Evasion Prosecution, Economica 71 (283), 349-368. 
Marrelli, M. (1984), On Indirect Tax Evasion, Journal of Public Economics 25, 181-96.

Marrelli, M. and R. Martina (1988), Tax Evasion and Strategic Behaviour of the Firms, Journal of Public Economics 37, 55-69.

Martin, S. (2001), Advanced Industrial Economics, Basil Blackwell.

Panteghini, P.M. (2000), Tax Evasion and Entrepreneurial Flexibility, Public Finance Review 28, 199-209.

OECD (2001), Consumption Tax Trends: VAT/GST, Excise and Environmental Taxes, Paris.

Sandmo, A. (2005), The Theory of Tax Evasion: a Retrospective View, National Tax Journal 58, No. 4, 643-663.

Shleifer, A. (2004), Does Competition Destroy Ethical Behavior?, American Economic Review (P\&P) 94, 414-418.

Slemrod, J. (2007), Cheating Ourselves: The Economics of Tax Evasion, Journal of Economic Perspectives 21, 25-48.

Slemrod, J. and S. Yitzhaki (2002), Tax Avoidance, Evasion, and Administration, in: Auerbach, A.J. and M. Feldstein (eds), Handbook of Public Economics, Vol. 3, Amsterdam: Elsevier, 1423-1470.

Virmani, A. (1989), Indirect Tax Evasion and Production Efficiency, Journal of Public Economics 39, 223-237.

Wang, L.F.S. (1990), Tax Evasion and Monopoly Output Decisions with Endogenous Probability of Detection, Public Finance Quarterly 18, $480-7$.

Wang, L.F.S. and J.L. Conant (1988), Corporate Tax Evasion and Output Decisions of the Uncertain Monopolist, National Tax Journal 41, 579-81.

Yaniv, G. (1995), A Note on the Tax Evading Firm, National Tax Journal 48, 113-120.

Yaniv, G. (1996), Tax Evasion and Monopoly Output Decisions: Note, Public Finance Quarterly 24, 501-5. 


\section{CESifo Working Paper Series}

for full list see www.cesifo-group.org/wp

(address: Poschingerstr. 5, 81679 Munich, Germany, office@cesifo.de)

2040 Rosario Crinò, Service Offshoring and White-Collar Employment, July 2007

2041 Carsten Hefeker and Michael Neugart, Labor Market Regulation and the Legal System, July 2007

2042 Bart Cockx and Muriel Dejemeppe, Is the Notification of Monitoring a Threat to the Unemployed? A Regression Discontinuity Approach, July 2007

2043 Alfons J. Weichenrieder, Profit Shifting in the EU: Evidence from Germany, July 2007

2044 Annika Alexius and Bertil Holmlund, Monetary Policy and Swedish Unemployment Fluctuations, July 2007

2045 Axel Dreher, Jan-Egbert Sturm and Jakob de Haan, Does High Inflation Cause Central Bankers to Lose their Job? Evidence Based on a New Data Set, July 2007

2046 Guglielmo Maria Caporale and Luis A. Gil-Alana, Long Run and Cyclical Dynamics in the US Stock Market, July 2007

2047 Alessandro Balestrino, It is a Theft but not a Crime, July 2007

2048 Daniel Becker and Michael Rauscher, Fiscal Competition in Space and Time: An Endogenous-Growth Approach, July 2007

2049 Yannis M. Ioannides, Henry G. Overman, Esteban Rossi-Hansberg and Kurt Schmidheiny, The Effect of Information and Communication Technologies on Urban Structure, July 2007

2050 Hans-Werner Sinn, Please Bring me the New York Times - On the European Roots of Richard Abel Musgrave, July 2007

2051 Gunther Schnabl and Christian Danne, A Role Model for China? Exchange Rate Flexibility and Monetary Policy in Japan, July 2007

2052 Joseph Plasmans, Jorge Fornero and Tomasz Michalak, A Microfounded Sectoral Model for Open Economies, July 2007

2053 Vesa Kanniainen and Panu Poutvaara, Imperfect Transmission of Tacit Knowledge and other Barriers to Entrepreneurship, July 2007

2054 Marko Koethenbuerger, Federal Tax-Transfer Policy and Intergovernmental PreCommitment, July 2007

2055 Hendrik Jürges and Kerstin Schneider, What Can Go Wrong Will Go Wrong: Birthday Effects and Early Tracking in the German School System, July 2007 
2056 Bahram Pesaran and M. Hashem Pesaran, Modelling Volatilities and Conditional Correlations in Futures Markets with a Multivariate t Distribution, July 2007

2057 Walter H. Fisher and Christian Keuschnigg, Pension Reform and Labor Market Incentives, July 2007

2058 Martin Altemeyer-Bartscher, Dirk T. G. Rübbelke and Eytan Sheshinski, Policies to Internalize Reciprocal International Spillovers, July 2007

2059 Kurt R. Brekke, Astrid L. Grasdal and Tor Helge Holmås, Regulation and Pricing of Pharmaceuticals: Reference Pricing or Price Cap Regulation?, July 2007

2060 Tigran Poghosyan and Jakob de Haan, Interest Rate Linkages in EMU Countries: A Rolling Threshold Vector Error-Correction Approach, July 2007

2061 Robert Dur and Klaas Staal, Local Public Good Provision, Municipal Consolidation, and National Transfers, July 2007

2062 Helge Berger and Anika Holler, What Determines Fiscal Policy? Evidence from German States, July 2007

2063 Ernesto Reuben and Arno Riedl, Public Goods Provision and Sanctioning in Privileged Groups, July 2007

2064 Jan Hanousek, Dana Hajkova and Randall K. Filer, A Rise by Any Other Name? Sensitivity of Growth Regressions to Data Source, July 2007

2065 Yin-Wong Cheung and Xing Wang Qian, Hoarding of International Reserves: Mrs Machlup’s Wardrobe and the Joneses, July 2007

2066 Sheilagh Ogilvie, 'Whatever Is, Is Right'?, Economic Institutions in Pre-Industrial Europe (Tawney Lecture 2006), August 2007

2067 Floriana Cerniglia and Laura Pagani, The European Union and the Member States: Which Level of Government Should Do what? An Empirical Analysis of Europeans' Preferences, August 2007

2068 Alessandro Balestrino and Cinzia Ciardi, Social Norms, Cognitive Dissonance and the Timing of Marriage, August 2007

2069 Massimo Bordignon, Exit and Voice. Yardstick versus Fiscal Competition across Governments, August 2007

2070 Emily Blanchard and Gerald Willmann, Political Stasis or Protectionist Rut? Policy Mechanisms for Trade Reform in a Democracy, August 2007

2071 Maarten Bosker and Harry Garretsen, Trade Costs, Market Access and Economic Geography: Why the Empirical Specification of Trade Costs Matters, August 2007 
2072 Marco Runkel and Guttorm Schjelderup, The Choice of Apportionment Factors under Formula Apportionment, August 2007

2073 Jay Pil Choi, Tying in Two-Sided Markets with Multi-Homing, August 2007

2074 Marcella Nicolini, Institutions and Offshoring Decision, August 2007

2075 Rainer Niemann, The Impact of Tax Uncertainty on Irreversible Investment, August 2007

2076 Nikitas Konstantinidis, Gradualism and Uncertainty in International Union Formation, August 2007

2077 Maria Bas and Ivan Ledezma, Market Access and the Evolution of within Plant Productivity in Chile, August 2007

2078 Friedrich Breyer and Stefan Hupfeld, On the Fairness of Early Retirement Provisions, August 2007

2079 Scott Alan Carson, Black and White Labor Market Outcomes in the $19^{\text {th }}$ Century American South, August 2007

2080 Christian Bauer, Paul De Grauwe and Stefan Reitz, Exchange Rates Dynamics in a Target Zone - A Heterogeneous Expectations Approach, August 2007

2081 Ana Rute Cardoso, Miguel Portela, Carla Sá and Fernando Alexandre, Demand for Higher Education Programs: The Impact of the Bologna Process, August 2007

2082 Christian Hopp and Axel Dreher, Do Differences in Institutional and Legal Environments Explain Cross-Country Variations in IPO Underpricing?, August 2007

2083 Hans-Werner Sinn, Pareto Optimality in the Extraction of Fossil Fuels and the Greenhouse Effect: A Note, August 2007

2084 Robert Fenge, Maximilian von Ehrlich and Matthias Wrede, Fiscal Competition, Convergence and Agglomeration, August 2007

2085 Volker Nitsch, Die Another Day: Duration in German Import Trade, August 2007

2086 Kam Ki Tang and Jie Zhang, Morbidity, Mortality, Health Expenditures and Annuitization, August 2007

2087 Hans-Werner Sinn, Public Policies against Global Warming, August 2007

2088 Arti Grover, International Outsourcing and the Supply Side Productivity Determinants, September 2007

2089 M. Alejandra Cattaneo and Stefan C. Wolter, Are the Elderly a Threat to Educational Expenditures?, September 2007 
2090 Ted Bergstrom, Rod Garratt and Damien Sheehan-Connor, One Chance in a Million: Altruism and the Bone Marrow Registry, September 2007

2091 Geraldo Cerqueiro, Hans Degryse and Steven Ongena, Rules versus Discretion in Loan Rate Setting, September 2007

2092 Henrik Jacobsen Kleven, Claus Thustrup Kreiner and Emmanuel Saez, The Optimal Income Taxation of Couples as a Multi-Dimensional Screening Problem, September 2007

2093 Michael Rauber and Heinrich W. Ursprung, Life Cycle and Cohort Productivity in Economic Research: The Case of Germany, September 2007

2094 David B. Audretsch, Oliver Falck and Stephan Heblich, It's All in Marshall: The Impact of External Economies on Regional Dynamics, September 2007

2095 Michael Binder and Christian J. Offermanns, International Investment Positions and Exchange Rate Dynamics: A Dynamic Panel Analysis, September 2007

2096 Louis N. Christofides and Amy Chen Peng, Real Wage Chronologies, September 2007

2097 Martin Kolmar and Andreas Wagener, Tax Competition with Formula Apportionment: The Interaction between Tax Base and Sharing Mechanism, September 2007

2098 Daniela Treutlein, What actually Happens to EU Directives in the Member States? - A Cross-Country Cross-Sector View on National Transposition Instruments, September 2007

2099 Emmanuel C. Mamatzakis, An Analysis of the Impact of Public Infrastructure on Productivity Performance of Mexican Industry, September 2007

2100 Gunther Schnabl and Andreas Hoffmann, Monetary Policy, Vagabonding Liquidity and Bursting Bubbles in New and Emerging Markets - An Overinvestment View, September 2007

2101 Panu Poutvaara, The Expansion of Higher Education and Time-Consistent Taxation, September 2007

2102 Marko Koethenbuerger and Ben Lockwood, Does Tax Competition Really Promote Growth?, September 2007

2103 M. Hashem Pesaran and Elisa Tosetti, Large Panels with Common Factors and Spatial Correlations, September 2007

2104 Laszlo Goerke and Marco Runkel, Tax Evasion and Competition, September 2007 